\title{
Fubilee Editorial
}

\section{British Cardiac Society-Golden Jubilee}

\author{
RAE GILCHRIST
}

\section{Consulting physician, Royal Infirmary, Edinburgh}

The British Cardiac Society had its origin in the Cardiac Club which consisted of 15 members bound together by their interest in cardiology. The Club held its first meeting in London in 1922 under the chairmanship of Sir Thomas Lewis and annually thereafter, with one or two new members added most years. As a source of lasting friendship, understanding, and good fellowship it made an indelible impression on its fortunate members. First and foremost, they were firm friends, united in a common interest in cardiology. I was astounded by the warmth of the welcome that I received on my admission to the club, only two members of which I had met previously. I felt I was among old friends.

At the Club's dinner after the annual meeting held in London in 1935, under the chairmanship of Sir Maurice Cassidy, I put forward the suggestion that the Club should expand, extend its benefits to a wider group, and act as a forum for the presentation of clinical research and discussion. I said we needed a British Cardiac Society with its own journal. Without any preliminary soundings before dinner, this proposal transformed the evening. It was seconded by Evan Bedford and received with enthusiasm with only one dissenter - Maurice Campbell - who subsequently changed his mind and a few years later became secretary of the new Society, soon to become the passion of his life! A constitution was drawn up and invitations were sent to 50 possible new members - all hand-picked; all accepted, and we were off to a good start.

We held our first annual meeting at the Royal Infirmary in Edinburgh in 1937 and I was Chairman that year. Among several communications that of Paul Wood was outstanding; he made a deep impression. The Society dined in the Hall of the Royal College of Physicians of Edinburgh. It was a memorable occasion, a dozen or more members accepting my invitation to continue the celebration of the successful birth of a new Society at my home, then within walking distance of the College. The Association of Physicians met the following day, dined in the same Hall, and only a few noticed that the caterers provided identical menus on successive nights.
In the early days it was an honour to be selected for membership of the Cardiac Club and of the British Cardiac Society as a foundation member. Now it is commonplace, but much appreciated by the younger $\vec{i}$ members who value the opportunity to see, hear, and 을 meet many of the leading cardiologists of the day, but perhaps on occasions a two-headed sword, as exemplified by a younger member telling me that having seen and heard a certain elder "statesman" take part in a discussion he (the younger) would never bother to read anything he (the elder) wrote in the future.

At one time all the members were known to each other. Those days have passed and now an enormous audience of members and guests gathers in one of two or three halls for simultaneous presentation of different communications, discussions, or lectures according to personal choice. The Society now consists of close on 800 members, of whom 200 or more reside abroad. It was in 1952, the year when the European Cardiological Congress was held in London, that Sir John Parkinson was elected our President. Similarly, in 1970 Sir John McMichael was President during the meeting of the World Congress of Cardiology in London. Professor Michael Oliver, the Society's eighth President and the first to be elected from outside London, brought Edinburgh an additional distinction.

The Society is responsible for two major publica- $\rightarrow$ tions - the British Heart fournal and Cardiovascular Research-both distributed world wide to sub- 응 scribers and making an enormous contribution to cardiology. The British Heart fournal was originally 0 intended for British contributors, thereby reflecting $\omega$ the British outlook, approach, and attitude to widening knowledge, but it now includes papers from all 0 over the world, recognition of its standing abroad.

In brief, the Society has attained a stature and a success greater than ever expected. Nevertheless, $T$ "small is beautiful" and the Cardiac Club in its per- $\frac{\vec{D}}{\mathbb{D}}$ sonal relationships had its own particular charm, $\stackrel{\mathbb{D}}{\stackrel{D}{\mathbb{N}}}$ denied to the larger, more efficient, but impersonal organisation of the present day. 


\title{
SOME NOTES ON THE CARDIAC CLUB
}

\author{
BY \\ JOHN COWAN AND OTHERS \\ "The Sun of our body, the King and sole Commander of it." \\ "Anatomy of Melancholy."
}

It is difficult to convey to the Georgian a proper impression of the attitude of the late Victorians to heart disease. Laennec's discovery of auscultation dominated the succeeding fifty years, and towards the end of the century the characteristic sounds of the various valvular lesions had been fully elucidated. For a time medicine stagnated. Those of us who were Residents in medical wards viewed the outlook with dismay, for the progress of surgery at that time, under the influence of Lister's work, was phenomenal. But better times were at hand.

The physiological laboratories were at work under Gaskell and others. The bacteriologists were turning their attention to medical subjects: the tubercle bacillus was discovered by Koch. X-rays showed the contents of the thorax. The sphygmomanometer was adapted for clinical use, and the polygraph and later the electrocardiograph added their quota to the general store.

But, although new methods of investigation became available, a personal influence was needed to speed up the work, and James Mackenzie became the centre of the picture. He had many facets. A tall, burly man, with all the directness of the North, he seemed at first sight rather dictatorial and overbearing; but his transparent goodwill, his unselfishness, and his humility soon made manifest that it was merely his intolerance of sham, and his search for truth. His intensive study of the Shorter Catechism had inculcated a downright mode of expression! He took a kindly interest in all his neighbours, especially the younger members of his profession : and he was always receptive of opinions based upon material which was outwith his own opportunities. Before long he had attracted to himself many men who were interested in the problems of heart disease; and had himself suggested to some of our members that a small club should be formed for meetings and discussions. The Cardiac Club was conceived in Burnley.

Another European war came, and our profession was scattered over the world. It was not a great war, for it altered little save garden fences, but it left a terrible swathe behind it. Many men had died, and many more were suffering in health, from wounds or sickness, for whom provision was required. During the war the Pension Service was necessarily a makeshift : the staff was insufficient and inexperienced, and their decisions needed revision and coordination. Many of the cases were cardiac, at least in name, so, in April 1920, the Ministry appointed Consultants to aid the Regional Directors in the assess- 
ment and treatment of the cardiac patients. The majority of those appointed had been associated with James Mackenzie before the war.

In 1921 a conference of the Consultants was held in London, and others subsequently. They were mainly concerned with the technical and administrative difficulties of the Ministry, but several interesting discussions upon purely medical subjects took place, and some valuable statistical data were collected. The influence of war service as a cause of subacute bacterial endocarditis : the effects of malaria upon the myocardium : the incidence of syphilitic disease of the heart ; the causes of death in chronic valvular disease; the value of quinidine in auricular fibrillation, etc., were considered.

The conferences were appreciated by those concerned (Carey Coombs, T. F. Cotton, John Cowan, Ivor Davies, Wardrop Griffith, John Hay, W. E. Hume, Thomas Lewis, J. E. Macllwaine, W. T. Ritchie, Robert Sevestre, H. J. Starling), who felt that they had been of service to themselves and perhaps to cardiac science, and that it was desirable that they should be continued under different auspices. On February 21, 1922, Hume wrote to Cowan (apparently considering him to be the most senior of the group, though Wardrop Griffith was in reality the doyen) suggesting that the men interested in heart disease should be called together at the next meeting of the Association of Physicians. Accordingly a meeting took place at Oxford, with A. G. Gibson in the chair, and on April 22, 1922, the Cardiac Club was born. The official accoucheurs were Carey Coombs, T. F. Cotton, John Cowan and W. E. Hume. The first active meeting of the Club took place in London later that year. A list of the original members and of those elected subsequently follows, with the dates of election of the extra-ordinary members.

\section{THE CARDIAC CLUB}

HONORARY MEMBER

James Mackenzie, F.R.S., Kt., 1915

Original Members

1922 Carey F. Coombs -1932

T. F. Cotton

John Cowan (Secretary, 1922-25) . . . . . . . . . 1930

J. G. Emanuel . . . . . . . . . . . 1933

A. G. Gibson (Secretary, 1925-28)

T. Wardrop Griffith, C.M.G. . . . . . . . . 1928

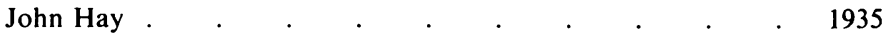

Thomas J. Horder, K.C.V.O., Kt. 1918, Bt. 1923, Baron 1933 . 1933

W. E. Hume, C.M.G.

Thomas Lewis, C.B.E., F.R.S., Kt. 1921. . . . . 1927

J. E. Macllwaine, $\quad-1930$

John Parkinson

W. T. Ritchie, O.B.E. (Treasurer, 1922-31) . . . . 1932

H. J. Starling

K. D. Wilkinson, O.B.E.

(British Heart Journal, Vol. 1, No. 1, January, 1939) 
THE CARDIAC CLUB-continued

\section{Members Elected SubSequently}

1923 J. Crighton Bramwell (Secretary, 1928-32)

Francis R. Fraser

1924 A. N. Drury, F.R.S.

C. E. K. Herapath, M.C.

1925 A. M. Kennedy

S. Wentworth Patterson

1926 George A. Allan

Maurice A. Cassidy, C.B., K.C.V.O., Kt. 1934

1927 S. B. Boyd Campbell, M.C.

Arnold W. Stott

1928 H. Wallace Jones

D. Evan Bedford (Secretary, 1932-36)

1930 E. P. Poulton

1931 J. Maurice Campbell, O.B.E. (Secretary, 1936-37)

1933 R. T. Grant, F.R.S.

A. R. Gilchrist

1934 Leonard Abrahamson

C. W. Curtis Bain, M.C.

1936 C. Bruce Perry

Of these original members, three have died : Carey Coombs in his full vigour in 1932, Macllwaine of Belfast in 1930, and James Mackenzie in 1925. At their next meeting the Club put on record this expression of appreciation of their only Honorary Member; and short notes of the dates and appointments of these three members follow.

Minute of the Cardiac Club, May 28, 1925

“"The Cardiac Club laments the death, on January 26, 1925, of its Honorary Member, Sir James Mackenzie. By the power of his genius and the wealth of his achievements he exercised a vast influence upon the branch of Medicine with which his name is indissolubly associated ; and his pre-eminence, transcending the limitations of race and clime, was universally acknowledged. So long as the Science of Medicine endures so long will the name of Sir James Mackenzie be honoured.

"This tribute is rendered to the memory of him whom all Members of the Cardiac Club revered as their Master; and the Club respectfully offers its sincere sympathy to Lady Mackenzie and Miss Mackenzie in the great loss which they have sustained." 
JAMES MACKeNZIE, 1853-1925

M.B., 1878 ; M.D., 1882 ; F.R.C.P., London, 1913. F.R.S., 1915. LL.D., Aberdeen, 1910 ; Edinburgh, 1911. Knight, 1915. Hon. Physician to H.M. the King in Scotland, 1920.

Physician, Victoria Hospital, Burnley ; 1880-1907. Physician, Mount Vernon Hospital for Diseases of the Chest ; 1910-18. Physician to the Cardiac Department, London Hospital, 1911-18. Director of the St. Andrew's Institute of Clinical Research, 1918-25. Schorstein Lecturer, 1911. Oliver Sharpey Lecturer, 1911. George A. Gibson Lecturer, 1914.

Carey Franklin CoOmbs, 1879-1932

M.B., 1901. M.D., 1903. F.R.C.P., 1917.

Physician, Bristol General Hospital, 1920. Director, Bristol University Centre of Cardiac Research, 1927.

Major, R.A.M.C., T.F. Served in England, Egypt, Mesopotamia and France, 1914-19. Long Fox Memorial Lecturer, 1925. Chadwick Lecturer, 1927. Lumleian Lecturer, 1930.

John Elder Macilwaine, 1874-1930

B.Sc. (Engineering) 1894. M.B., 1901 ; M.D., 1904 ; D.P.H., 1907.

Physician, Royal Victoria Hospital, Belfast, 1910-29. Professor of Materia Medica and Therapeutics, Queen's University, Belfast, 1921-28.

Irish Rugby International, 1897-99.

Dresser, Irish Hospital, South Africa, 189.9-1900. Physician, St. John's Ambulance Brigade Hospital, France, 1915-17.

The First Annual Meeting of the Cardiac Club was held at University College Hospital, London, under the chairmanship of Sir Thomas Lewis on November 22, 1922 and, subsequent meetings have been held on the day previous to the annual meetings of the Association of Physicians, wherever the Association happened to meet.

Many subjects have been discussed by the Club: the heart in the acute infections ; hyperpiesis ; angina pectoris ; infarct of the heart ; heart block ; the heart in pregnancy ; cardiac asthma ; vaso-vagal attacks ; the treatment of œdema ; etc. In addition to the set subjects many short discussions upon case records, electrocardiograms, pathological specimens, etc., have also taken place, to the obvious pleasure of the members. On several occasions demonstrations have been given to the Club by those working in the laboratories. A list of the main subjects discussed at each meeting follows with the names of those who introduced the discussion. 
In addition to the value the members have received from the meetings, the most important function of the Club has been the promotion of friendship between the members. All of us, from time to time, have received help from our confrères by advice or the supply of information or material. On two occasions the Club has been responsible for the mass collection of material from the members, from which important conclusions were drawn and made public at an earlier date than would have been possible if all the data had been dependent upon one observer. We refer to Hay's paper upon the value of quinidine in the treatment of auricular fibrillation and to Gibson's paper upon ischæmic necrosis of the heart. It seems desirable that this procedure should be repeated as occasion demands.

Webb's egg has grown and the stripling is thriving. Under the new constitution we anticipate a strong and healthy adult life.

JOHN COWAN AND OTHERS

General Meetings of the Cardiac Club

1922. April 22.

Oxford

Chairman, A. G. Gibson

Decision to form the

Cardiac Club

1922. November 22. University College

Hospital, London

First General Meeting , Sir Thomas Lewis

1923. May 17.

Edinburgh

, W. T. Ritchie

1924. June 5.

Bristol

1925. May 28

Royal Soc. of Medi-

1926. May 20.

1927. June 2.

1928. May 24.

1929. April 4.

1930. June 5.

1931. May 21.

1932. May 12

1933. April 6.

1934. May 7.

1935. June 6.

1936. May 28.

, Carey Coombs

1937. January 8 cine, London

Newcastle

Belfast

Liverpool

Cambridge

The London Hospital, London

Manchester

Liverpool

Glasgow

Leeds

St. Thomas Hospital, London

Manchester

T. F. Cotton

, W. E. Hume

J. E. Macllwaine

, John Hay

, A. N. Drury

Fifteenth and last General Meeting of the Cardiac Club.

An Extra-Ordinary Meeting was held at Guy's Hospital, London (Chairman, Bramwell) at which it was decided that the Cardiac Club should be transformed into the Cardiac Society of Great Britain and Ireland. 
Main Subjects of Discussion

1922. Infective Endocarditis

1923. The Use of Quinidine Abnormal QRST Complexes

1924. The Heart in Pneumonia Digitalis

The Effect of Adrenalin on the Heart Heard Disease in Children

1925. Anæmic Necrosis of the Heart Simple Tachycardia Blood Pressure Cardiovascular Syphilis

1926. The Heart in Hyperpiesis Angina Pectoris

1927. Heart Block Treatment of GEdema

1928. Angina Pectoris Injection of the Coronary Arteries

1929. Cardiac Asthma Vaso-vagal Attacks

1930. Mitral Stenosis The Heart and Athletics

1931. Ætiology of Heart Disease

1932. The Heart in Diphtheria The Heart in Influenza The Influence of Tobacco The Influence of Alcohol

1933. Abnormalities of the $T$ wave Right and Left Ventricular Complexes

1934. Diseases of the Pulmonary Artery Vaso-motor Angina

1935. Heart Symptoms and Gall Bladder Disease

Cardiac Disease of Unknown Ætiology

1936. Heart Disease and Pregnancy Heart Block
Sir Thomas Horder

Hay and Parkinson

Macllwaine

Wardrop Griffith

Fraser and Andrus (introduced).

Hume and Fraser

Cotton and Carey Coombs

Gibson

Parkinson

Bramwell and Carey Coombs

Cotton

Wilkinson

Starling

Kennedy

Patterson

Ritchie

John Campbell (introduced)

Fraser and Emmanuel

Starling

Cowan

Bramwell

Carey Coombs

Hume and Wilkinson

Herapath

Maurice Campbell

Patterson

Cowan and Allan

Drury

Parkinson and Bedford

Cassidy and Patterson

Cotton and Hume

Stott and Maurice Campbell Bramwell

Gilchrist 


\section{THE CARDIAC SOCIETY}

After the meeting of the Cardiac Club in 1935 it was suggested that, with the increasing numbers who were interested in Cardiology, the time might have come for expanding into a larger and more representative society and that the Executive should consider this possibility.

At the 1936 meeting in Manchester a memorandum which had been drawn up by the Executive (Allan, Bedford, Drury and Wilkinson) provoked a long discussion. After general approval of the principle of expansion the following committee was appointed to draw up a scheme for submission to a special meeting of the club.

Members : Evan Bedford, Crighton Bramwell, F. R. Fraser, John Parkinson and Maurice Campbell (Secretary).

The committee held several meetings and drew up a draft constitution and rules for the Cardiac Society, and lists of names of those who should be invited to be Honorary, Extra-Ordinary, Ordinary and Associate members.

The last meeting of the Cardiac Club was a special one held in the Governor's Committee Room at Guy's Hospital on January 8, 1937. It was decided to accept these proposals for the formation of the new society, for its rules and constitution, and for the names of those who were invited to be the original members. The following were chosen as the first Council : Allan, Evan Bedford, Crighton Bramwell, Gilchrist (President 1937), Parkinson, Wilkinson and Maurice Campbell (Secretary and Treasurer).

At the First Annual Meeting of the Cardiac Society, held at Edinburgh on April 15, 1937, practically all the members attended, and in addition to the scientific business a committee was appointed to consider the possibility of starting a journal dealing with cardiology. Members: Gibson (Chairman), Evan Bedford, Maurice Campbell, Fraser and Wilkinson.

Several meetings were held, and in February 1938 the committee reported to the Council. They recommended that such a journal should be started and that the British Medical Association should be asked to publish it, as after various negotiations and meetings they thought that the British Medical Association were able and willing to publish a journal that would meet the needs of the Society. These recommendations were approved by the Council of the Cardiac Society, which appointed the Editors and the Editorial Board for the Journal. The title which has been chosen was suggested at an early stage, but many other titles have had their supporters. The action the Council had taken with reference to the Journal was approved by the Society at its Second Annual Meeting at Bristol on June 2, 1938.

MAURICE CAMPBELL,

Secretary of the Cardiac Society.

(British Heart Journal, Vol. 1, No. 1, January, 1939) 


\section{BRITISH HEART JOURNAL. EDITORIAL NOTE}

For some time the need for a journal representative of British Cardiology has been apparent, and the Cardiac Society of Great Britain and Ireland, feeling assured of adequate support, has taken the initiative in starting the British Heart Journal. The Society's project has been facilitated by the generous co-operation oft he British Medical Association, which has undertaken the responsibility of publishing and distributing the Journal.

To those who hold that specialization has already gone too far, the appearance of another journal devoted to a special branch of medicine may seem a step in the wrong direction. In Harvey's time medicine had no offspring, for the surgeon was no more than the servant of the physician. One by one, Anatomy, Physiology and Pathology began to develop independently of the parent science, and in the course of time further separation has occurred, to meet the exigencies of practice, teaching, and research.

But even traditional divisions in medicine are not inviolate, and already the barrier between Medicine and Surgery is yielding, for example in the fields of Neurology and of Diseases of the Lungs. Radiology has become a special branch of medicine on grounds of expedience alone, for it is no more than a method of examination, and incidentally one which is readily applicable to the heart. Cardio-vascular radiology has been and is being developed as a means of diagnosis by those interested in the heart, whether primarily physicians, radiologists, anatomists or physiologists. The special journal represents an attempt at reorientation; its proper function is to bridge the barriers separating existing divisions in medicine, and not to create new ones. By providing common ground on which physicians, anatomists, physiologists and pathologists may meet and pool their efforts in a particular direction, it enables those who treat the sick and those who work mainly in the laboratory to keep in contact with each others problems in the same field, to their mutual advantage.

The British Heart Journal will naturally reflect first and foremost the interests of members of the Cardiac Society, interests that are predominantly though not exclusively centred in the clinical aspects of cardio-vascular disease ; but the policy of the Journal, and indeed of the Society, will be to serve all those interested in the Heart and Circulation, irrespective of their calling.

In starting the British Heart Journal, we are not unmindful of its predecessor, Heart, founded by Sir Thomas Lewis nearly thirty years ago. During the period when knowledge of electrocardiography was developing, Heart rendered invaluable service to Cardiology and maintained a standard and reputation second to none among the scientific journals of the world. In changing the title to Clinical Science, Sir Thomas Lewis has indicated his intention of widening its scope and thus increasing its field of usefulness to those engaged in research. The Cardiac Society are indebted to him for his generous co-operation, and we take this opportunity of thanking him for his support and for contributing a foreword.

D. EVAN BEDFORD. 